ELORE (ISSN 1456-3010), vol. 17 - 1/2010.

Julkaisija: Suomen Kansantietouden Tutkijain Seura ry. [http://www.elore.fi/arkisto/1_10/ajankoht_klinkman_1_10.pdf]

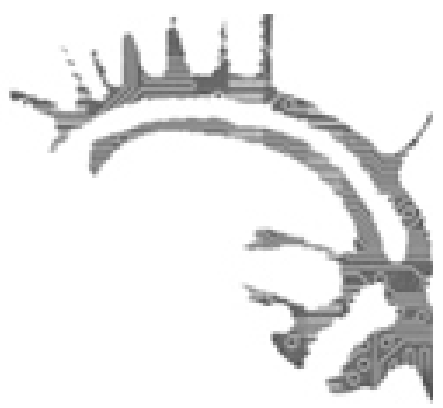

\title{
Aktuellt
}

\section{AtT STUdera Det SVEnSKa i Finland SOM ETT PUSSEL}

\section{$\underline{\text { Sven-Erik Klinkman }}$}

Fem folklorister, en sociolog och en kulturgeograf vid Åbo Akademi börjar med start i sommar forska om det svenska i Finland inom ramen för ett forskningsprogram som utlysts av Svenska litteratursällskapet i Finland. Projektet beräknas vara klart i slutet av år 2012, och resultera i bland annat en antologi. Syftet med projektet är att belysa hur det svenska i Finland framställs i sociala och kulturella processer som svar på de utmaningar som finns i dagens samhälle. Materialet består av debatter i media, skolans historieböcker, frågelistor och intervjuer.

Tanken är att studera det svenska i Finland som ett slags pussel karaktäriserat av sektioner som är relaterade till varandra genom maktförhållanden av olika slag. Genom att sammankoppla identitets- och mentalitetsstudier med aktuell forskning vad gäller intersektionalitet och strategier för coping inom en kollektiv ram vill forskargruppen visa på nya möjligheter att kulturanalytiskt närma sig frågor om etnicitet, minoritet, gemenskapskänsla, gemenskapsbild och självbild. De enskilda forskarna kommer att använda sig av olika teoretiska verktyg för sina projekt. Både diskursanalys, narratologisk teori, teorier om metaforer och retorisk analys används för att kunna bända upp en problematik som inte är lätt att komma åt, nämligen frågor om hur man skapar tillhörighet inom ramen för det svenska i Finland.

\section{INTERSEKTIONALITET SOM TEORETISK RAM}

Ett nyckelbegrepp i analyserna utgörs av frågeställningarna om intersektionalitet. Med sitt fokus på makt och motstånd är det intersektionella perspektivet ett speciellt rikt och därmed också komplext analysredskap. Genom att anlägga intersektionella perspektiv på belägenheter och dilemman som uppstår i debatter och på andra platser för kulturmöten gällande det svenska i Finland menar gruppen att nya insikter ska kunna friläggas om den mångbottnade och ofta paradoxala karaktären hos det 
svenska i Finland. Det gäller inte minst det som betecknas som det finlandssvenska, alltså en diskursiv, ideologiskt färgad, kollektiv konstruktion.

Projektet utgår ifrån att det svenska i Finland står mellan det finska och det rikssvenska. Positionen är förknippad med utmaningar men även med dynamik och möjligheter. Begreppet och idén om "finlandssvenskhet" uppstod ur en specifik historisk situation genom en framgångsrik konsoliderings- och mobiliseringsprocess. Det finlandssvenska präglas å ena sidan av en stor diversitet, å andra sidan av en övergripande tanke om gemenskap, homogenitet, närhet och litenhet ("ankdammen"). Idag, när identitet framträder som ett personligt projekt och många traditionella anknytningar (som politiska partier) inte längre är självklara och livslånga, blir individens personliga förhållande till det svenska i Finland allt mer avgörande.

Debatterna hoppas vi ska kunna peka på de inbyggda komplexiteter och dilemman, men också möjligheter till anpassning, coping, motstånd, som ingår i den finlandssvenska identitetskonstruktionen. Vi hoppas dels kunna visa hur mångsidig och mångtydig bilden av den finlandssvenska verkligheten eller de finlandssvenska verkligheterna - pusslet - kan te sig, speglad genom debatt och kulturmöten. Dels vill vi visa hur beskrivningen av det svenska hela tiden söker olika kristalliseringspunkter, för att framstå som tydlig och given, historiskt inskriven, i form av bland annat starka dikotomier, som kultursvensk/bygdesvensk, lokalt/nationellt, enspråkigt/tvåspråkigt.

\section{De ENSKILDA PROJEKTEN}

Folkloristen Mikael Sarelin undersöker möten mellan spinnfiskare och skärgårdsbefolkning och de konflikter som uppstår som en följd av dessa möten. Spinnfiskarna utgörs ofta av finsktalande män, medan de mest synliga skärgårdsborna oftast utgörs av svenskspråkiga män. Utöver språkfrågan och regionfrågan aktualiseras också frågor kring klasstillhörighet, genus och arbete. Sarelin baserar sin forskning på intervjuer och deltagande observation. Han vill reda ut hurdana bilder respektive grupp (spinnfiskare och lokalbefolkning) målar upp av den Andre och hurdana uttryck mötena mellan de två grupper kommer att ta.

Kulturgeografen Patricia Aelbrecht vill se hur den förändrade språkliga strukturen i skärgården uppfattas och formuleras, detta genom en jämförande studie av Korpo och Brändö (Åland). Att jämföra de olika coping-strategierna, på såväl svenskspråkigt som finskspråkigt håll, i två skärgårdsområden som båda är utsatta för ett språkligt och kulturellt förändringstryck bidrar till ny kunskap om problematiken om språk, minoritet/majoritet och kulturell identitet. Materialet för hennes delstudie baserar sig på såväl intervjuer med den lokala befolkningen och artiklar och debattinlägg $\mathrm{i}$ tidningar, som demografisk statistik och kartor.

Religion är ett tema som ofta väcker debatt i finlandssvensk press. Sociologen Andreas Häger studerar en debatt som rör religion, mer specifikt inlägg om den laestadianska väckelserörelsen i norra svenska Österbotten. Den studerade debatten berör hur den laestadianska gruppen passar eller inte passar in i den finlandssvenska gemenskapen. Återkommande teman i denna debatt gäller de normer som råder inom laestadianismen. Ett centralt debattema är könsroller och reproduktion, ett annat är 
ungdomars förhållande till regler och ordning. Två debatter som Häger ska studera närmare gäller dels en våg av anklagelser om djurplågeri i en by där en betydande del av befolkningen är laestadianer, och dels frågan om laestadianska könsroller. Materialet består av tidningsdebatt ur den tryckta pressen, läsares kommentarer till artiklar i nätversioner av finlandssvensk dagspress, samt av diskussion på finlandssvenska bloggar och nätfora. Materialet är i huvudsak från åren 2008 och 2009.

Folkloristen Blanka Henriksson undersöker den så kallade snusdebatten som fördes i Finland år 2008. Hon vill undersöka denna debatt ur ett maktperspektiv, där det upplevda hotet inte bara är ett förbud mot ett preparat utan också en begränsning av ett finlandssvenskt handlingsutrymme. Snusförbudet upplevs av vissa som ett förbud mot att låta människor uttrycka sin finlandssvenskhet på ett visst sätt. Fenomenet undersöks genom att blottlägga de olika diskurser som förekommer i debatten och studera hur man skriver sig till finlandssvenskhet i en offentlig debatt som till synes handlar om någonting helt annat än det finlandssvenska. Fokus kommer att ligga på de retoriska grepp som används av både snusförespråkare och snusmotståndare.

Folkloristen Sofie Strandén undersöker i delprojektet "Slaget om ortnamnen" hur man framställer sin identitet genom retoriska konstruktioner i debatten kring de svenska ortnamnen i Finland, som Paula Wilsons bok Röster frän forntiden. Gamla ortnamn berättar (2007) åstadkom i pressen. I framför allt Vasabladet och Hufvudstadsbladet fick man vintern 2007-2008 ta del av en stundom hätsk debatt mellan förespråkare för Paula Wilsons tolkning av finlandssvenska ortnamn och andra som sällade sig till den etablerade ortnamnsforskningen i landet. En intersektionell analys av debattmaterialet i dessa båda dagstidningar ställer fokus på relationerna mellan dikotomier som kultursvensk/bygdesvensk, vetenskapare/lekman, man/kvinna, elit/folk, stad/ landsbygd, finländsk kulturgemenskap/svensk eller germansk kulturgemenskap.

Folkloristen Johanna Björkholm vill i delprojektet "De svenskspråkiga finländarnas historia framställd genom läroböcker" undersöka framställningar av finlandssvenskar och "finlandssvenskhet" i läroböcker i historia. Utgångspunkten är att beskrivningar av finlandssvenskarnas historia kan anses innehålla coping-strategier, så att historien skrivs om för att ge en gynnsam bild av den svenskspråkiga gruppens historia enligt rådande samhällsströmningar. Beroende på den historiska kontexten kan bland annat kultursvenskhet respektive bygdesvenskhet eller tvåspråkighet ha varit strategiskt viktiga att framhäva. Historieböckernas framställningar har inte mottagits passivt, utan de har tidvis debatterats i offentligheten. Björkholm intresserar sig såväl för åsikter som uttryckts på dagstidningarnas debattsidor som inom yrkesspecifika lärartidningar. Studien upptar såväl röster från yrkesverksamma lärare och akademiker som från den intresserade allmänheten.

Folkloristen och populärkulturforskaren Sven-Erik Klinkmann, som också är ledare för projektet, undersöker användningen av performativa, ironiska uttryck om finlandssvenskarna, som exempelvis "Ankdammen", "Pappa betalar", "Älä löi en ole hurrit", "Svenskatalande bättre folk", utgående ifrån ett retoriskt perspektiv av det slag Michael Billig tillämpat. Klinkmann undersöker i vilka sociala, performativa och diskursiva sammanhang dylika ironiska vändningar används i den samtida debattkulturen i Finland, med en speciell fokus på frågor som handlar om identitetskonstruktion, 
Sven-Erik Klinkman: Att studera det svenska i Finland som ett pussel

performativitet och synlighet. På vilka sätt kan a) de retoriska, mer eller mindre pejorativa uttrycken bindas till diskussionen om stereotypisering av en i detta fall språklig minoritet och b) vilken betydelse har de ironiska uttrycken för konstruktionen av finlandssvenskarnas självbild och frågor om kulturell gemenskap? Som material för Klinkmanns undersökning används material som ingått i tidningar, bloggar, böcker, tv och andra media under 2000-talet.

Sven-Erik Klinkmann är docent i folkloristik, särskilt populärkultur, vid Åbo Akademi. Han arbetar för närvarande som forskare vid Svenska Litteratur Sällskapet, med ett bokprojekt om det svenska i Finland. 